\title{
PUBLISH AND PERISH: ON THE MARTYRDOM OF PHILIPP NICODEMUS FRISCHLIN
}

Scholars interested in Nicodemus Frischlin (1547-1590), the epigonal Protestant humanist known chiefly for his Neo-Latin play, Julius Redivi$v u s$, are still indebted to David Friedrich Strauss, whose biographical study remains the major monument of Frischlin scholarship. ${ }^{1}$ The controversial Strauss was drawn towards controversial figures as biographical subjects. To Hutten and Schubart Strauss drew considerable attention, but he aroused only slight interest in Frischlin until long after publication of the book. Among Strauss's many publications, his Frischlin biography stands alone as a commercial failure. Until someone appears to reassemble the necessary material and traverse anew the ground Strauss so laboriously and thoroughly (and for the reader so painfully) covered, his work will remain the single most useful documentation of Frischlin's life in spite of the infelicities of its style. However, we may well question its author's interpretation of the rich material it offers.

Reinhold Stahlecker was the first to fault seriously the picture Strauss drew of Frischlin. ${ }^{2}$ Seeking to clear the name of Frischlin's enemy and Strauss's arch villain, Martin Crusius, Stahlecker challenged Strauss's portrayal of Frischlin as a martyr. When one has sorted through Stahlecker's arguments, a good deal of which is Nazi absurdity, one must concede that there is some justice in his account of the Frischlin-Crusius conflict. Stahlecker dwells upon those obvious personal weaknesses in Frischlin's character which Strauss tended to treat with an all-too-forgiving indulgence. Neither scholar can be accused of historical objectivity. Strauss sought to cast Frischlin in the mold of Schubart and Hutten. After Stahlecker, this mold will no longer fit Frischlin. But this is so for reasons which Stahlecker would probably not have been quick to see or accept, for martyrs have come upon rather difficult times. Modern depth psychology has taught us to be skeptical of all men's motivations, the felon's and the victim's alike. This is a skepticism foreign to both Strauss and Stahlecker, and while admittedly disconcerting, it is a healthy attitude for the literary biographer to develop. ${ }^{3}$

Using the biographical material available, which aside from Strauss's book is rather scant, I will try in this essay to give a brief account of Frischlin's ,martyrdom", an account hopefully unmarred by the jingoism found in a good portion of Frischlin scholarship. I will particularly focus upon several bizarre and apparently inexplicable episodes in Frischlin's life, seeking to bring reason to bear upon what Strauss was forced to shrug off and Stahlecker but to condemn. For a more detailed account of the controversies surrounding Frischlin one should of course consult Strauss. From Strauss it is clear that Frischlin's life was a tangle of conflict, characterized by a succession of quarrels, broken friendships, shifting personal 
alliances, with its limited initial successes reversing to an extensive, ultimately catastrophic, failure. Frischlin's was a life marked by ambivalence; known to his contemporaries as a most gifted and prolific Latinist, his esteem was marred by his not entirely unwarranted reputation as a troublemaker.

In his twenty-first year, after five years of study at Tübingen, Frischlin there secured an appointment as professor extraordinary of poetics and history. In the same year, 1568, he married Margarete Brenz, a member of a prominent Protestant family in Württemberg. Her great-uncle, Dr. Johann Brenz, a friend and ardent supporter of Martin Luther, had been the area's first reformer. Frischlin's wife was strong-willed and the marriage does not seem to have been a dull one. Frischlin's relationship with colleagues and superiors in his first years as a lecturer appear congenial. In 1570 Martin Crusius stood as godfather to Frischlin's first-born son. $\mathrm{He}$ also wrote a letter of recommendation for the young Magister which Frischlin took to the Imperial Diet at Speyer. Having composed an epithalamium on the occasion of the marriage of the Emperor's daughter, Frischlin made a plea to be crowned poet laureate, hinting also at the additional honor of comes palatinus. ${ }^{4}$ For an untried young poet to petition the Imperial court for such honors seems audacious, and the incident reveals an essential aspect of Frischlin's character: his consuming social ambition. The first signs of dispute between Frischlin and Crusius appear in what Frischlin considered a social slight by his senior colleague. ${ }^{5}$ But at the same time Frischlin was beginning to secure support from the ducal court in Stuttgart. The godfather of his second son was the cousin and eventual successor of Duke Ludwig. Strauss (pp. 57-59) relates in some detail the real financial difficulties confronting the young Frischlin, a man of no means other than his wife's small allowance. His rapidly growing family and his increasing obligations as a teacher caused him great distress. Both his ambition and his discontent increased when his needs were ignored by the university senate, despite ducal intercession on his behalf.

In January 1576 Frischlin was granted a recommendation from the senate which lauded him as a scholar and teacher, significantly making but guarded allusion to his moral qualities. Why this was done we may only guess, but Strauss (pp. 62ff.) relates an incident of the following summer which may explain the senate's discretion. While inebriated, Frischlin and a couple of student companions became involved in a shouting match with a certain lady of the nobility, the upshot of which was several broken windows in the lady's domicile and a university hearing on Frischlin's behavior. The incident was to further haunt Frischlin. If we may surmise that other, less public incidents preceded this one, we are able to account for the reluctance of the senate to make a statement concerning Frischlin's moral stature. Rarely one to show discretion, Frischlin here and elsewhere appears to behave precisely in that manner which would most likely thwart his ambition. Yet in spite of his self- 
defeating conduct, he was able in this instance to retain his academic position, his potential promotion made contingent upon self-improvement.

In the meantime, however, Frischlin used the senate's recommendation, coupled with Duke Ludwig's, to secure in 1576 the previously sought poet laureateship. At the same time Rudolph II granted him the lesser order of nobility, naming Frischlin comes palatinus.

The consternation caused in Tübingen by these Imperial favors is not hard to imagine: Frischlin's colleagues on the faculty of the university were intensely jealous of the able and ambitious, yet sanguine and convivial man. With very few exceptions they were now becoming confirmed in their attitude of growing hostility toward him ${ }^{6}$.

Denied the desired and fortuitously vacant senate position in 1577 , Frischlin ceased lecturing and demanded promotion. The Duke interceded and an extraordinary compromise was reached whereby Frischlin was accorded all of the many substantial privileges and benefits of senate status, though without the title and without the formal vote. This was to satisfy Frischlin but for two years: more than substance, his ambition required form. On the pretext of seeking a position elsewhere, Frischlin asked for and received another laudatory recommendation from the senate which he immediately submitted along with an impressive list of publications (see Strauss, p. 155) to that same body, asking for senate status. Clever, though transparent, this maneuver failed, endearing Frischlin to his senior colleagues not at all.

Shortly thereafter there came a call from the university at Freiburg im Breisgau, a Catholic institution, on terms which generously allowed him to maintain his own Lutheran persuasion. Frischlin journeyed to Freiburg, concluded the arrangements, and on his return to Tübingen was met with the refusal of his wife to move to the papist city. Margarete was ill-disposed towards her husband at this time in any case, for in his absence she had discovered, through the abysmal stupidity of Frischlin's younger brother, Jakob, that he had been unfaithful. The female involved was a young seamstress who had often worked in the Frischlin household. Even before her husband had returned from Freiburg, Margarete Frischlin had openly complained to her many influential relatives of her spouse's infidelity. All of this became common knowledge in the city and was to be ammunition for his enemies some seven years later. Frischlin was forced to cancel his appointment to the faculty at Freiburg.

From this point Frischlin's difficulties multiply rapidly. Now suspected of papist leanings, he struggled to re-establish publicly his own strict Lutheran orthodoxy. He also entangled himself in a damaging dispute with the minor gentry, a dispute whose origins were probably personal and not philosophical. Having cultivated many friends among the upper nobility of the land, and having secured his own minor title, Frischlin was apparently bold enough to consider himself the equal of his many unlettered but noble drinking companions. There can be no doubt that the 
quick-witted and acid tongued Frischlin began to rub certain of these men the wrong way, becoming finally the object of their amusement. In June 1580 Frischlin traded drunken insults with the Bailiff of Tübingen, Fritz Herter von Herteneck, whereupon the latter pulled Frischlin's hat down over his ears. While Frischlin felt wronged, the matter was temporarily settled (with the Duke's intercession), though not altogether amicably. Herter came into possession of a Frischlin oration, De vita rustica, which he then had translated into a quite spurious German. Originally composed in 1578, Frischlin intended to use it as an introduction to a paraphrase of Virgil's Georgics and Bucolics. Frischlin was called to account for statements on the decadent state of the bourgeoisie and aristocracy. The oration implies that true virtue lies in the hands of the peasantry. The rather recent memories of his age's Peasant Wars lent such statements a revolutionary air. Feelings ran high and while Frischlin did not recant, he did claim that he was misunderstood, a disingenuous attempt to disarm his critics. He was completely unsuccessful in this, and he seems ever hereafter to have lived in actual fear for his life. He was forced to endure on several occasions embarrassment, harassment, and abuse at the hands of his enemies. After a period of intense pamphleteering by both parties to the dispute, a truce was worked out by Duke Ludwig. But when a Saxon theologian published a diatribe against him, Frischlin wasted no time in answering it, petitioning the Imperial Court for protection. This strained the benevolence of the Duke, for Ludwig was offended that Frischlin should go over his head to the Emperor. The whole affair, from Herter's insults to the Duke's well earned ire, shows Frischlin in a typically combative posture. That in defending himself blindly he often hurt friend as well as foe was to haunt him in the future. ?

Frischlin left Tübingen in 1582 to take over the rectorate of the Protestant gymnasium in Laibach on what was then the Empire's Turkish border. He was under written obligation to write no more concerning his various disputes with faculty and nobility at home. This promise he promptly broke, claiming that it was binding only if his enemies reciprocated his silence. In Laibach Frischlin completed his Latin school grammar. $\mathrm{He}$ arranged for its publication by the famous Venetian Aldine Press. This grammar placed Frischlin in direct competition with Martin Crusius, whose own grammar was then in wide usage. Frischlin was released from his three-year contract with the gymnasium after but two years. He returned to Tübingen with a laudatory letter from the authorities in Laibach. It is not farfetched to suppose that this letter was written to escape retribution from the combative Frischlin. Frischlin claimed that his wife's homesickness dictated his return. From what we know of Margarete Frischlin, this claim seems credible.

Frischlin was unable to secure a position either in Tübingen or elsewhere in spite of Duke Ludwig's warm recommendations. To the faculty at Tübingen, Frischlin, however gifted, was an incorrigible troublemaker. 
Caught in a limbo, Frischlin now sought to have printed a collection of his various poetic, philological, and scientific writings. Permission for this was only grudgingly given. ${ }^{8}$ Only the favor of the Duke now sustained Frischlin, a favor Frischlin earned by his production of Julius Redivivus and his poetic description of the nuptial festivities which were its occasion. Believing his opportunity of securing a faculty position at Tübingen foreclosed, Frischlin now sought to change his profession. He petitioned the Duke for one year's support to complete a course in medicine. This raises some question concerning Frischlin's basic motivation. While he could have made the change rather easily, such a step, even then, was a rather radical one. Even if we grant the severe difficulty Frischlin was in, we may begin to question his commitment to the profession of letters. Was his profession merely the extrinsic instrument by which he sought esteem? If it was, then Frischlin's tremendous admiration for Cicero, the philosopher of ambition, appears quite comprehensible. Whatever we conclude, no action was taken on Frischlin's request to study medicine. Rather, the Duke made a final attempt to place Frischlin in the senate at Tübingen. This effort might have succeeded had not a new taint of personal scandal now come to rest upon Frischlin.

Frischlin's opponents found a way to avoid giving offense to the Duke and in turn to lower his high regard for Frischlin. Frischlin was charged with two counts of adultery and one count of manslaughter. While Frischlin was exonerated from the manslaughter charge and from one of the alleged incidents of adultery, his admitted dalliance some years earlier put him in a bad position especially since the Duke was somewhat phobic on the subject of adultery, and he had made the penalties for the crime quite severe. Forewarned of a summons to a hearing in Stuttgart, Frischlin fled to Frankfurt am Main where he released a broadside printing of a farewell ode to Tübingen. It was a masterpiece of venom which covertly cited all manner of scandal, private and public, concerning men of influence and stature in the city. ${ }^{9}$ The poem was circulated throughout the Empire, mortifying Frischlin's foes, but more significantly, shocking even the closest of his friends. ${ }^{10}$ This action, more than any other, was to clear the way for his eventual incarceration. Frischlin's property was impounded and only by promising henceforth to write neither about the nobility nor the university was he able to dispose of it. He left Tübingen for the last time in late 1586.

Now an exile, Frischlin began the life of an unwanted wanderer. Since he was known as a truly gifted man, Frischlin generally found ready hospitality but no offers of a permanent academic position. It is unlikely that, as Strauss supposed, a conspiracy headed by Crusius was at work against Frischlin. More simply, those in positions of authority feared his vitriolic pen too much to risk taking him in permanently. To be sure, honoraria and official praises were rendered in many places. He even secured an Imperial copyright for his publications, but that ended the 
favors extended by the court at Prague.

Frischlin now involved himself in a paper war with Crusius, who had responded to Frischlin's initial attacks against him and his grammar in kind. From a philological standpoint, Frischlin was more often correct in the specific grammatical questions. On both sides, however, the bulk of the arguments were of a rather low order; most of their pamphlets and counterpamphlets are exercises in character assassination and are to neither man's credit. They were especially injurious to Frischlin in Württemberg since he was obviously ignoring his agreement with the Duke. He even dared to dedicate the first of his new series of pamphlets against Crusius to Ludwig. In the course of his correspondence with friends in Stuttgart he also proclaimed now that his allegiance was to the Emperor alone, that he had no intention of ever returning to his homeland, and that he could, if he wished, publish all manner of scandal concerning the regime in Stuttgart. He signed a letter to Melchior Jäger, ,K. K. Majestät Böhmischer Historicus und Bibliothecarius." 11 These are titles never conferred upon him by anyone, least of all the Emperor. This was not the only time Frischlin claimed titles and perquisites not properly his.

Frischlin secured nothing substantial at the Imperial court nor from the publication of his varied works with their dedications to various other princes. He moved on to Wittenberg in September 1587 where he established himself as a Privat-Dozent. It was daring of Frischlin to appear in Philippist Wittenberg after the uproar his comments about the outdatedness of Melanchthon's grammar had caused. The lot of a Privat-Dozent was at the time not a happy one and when in March of the next year the offer came from his friend and countryman, Polycarpus Leyser, of the rectorate of the Lateinschule in Braunschweig, Frischlin accepted it and moved from Wittenberg after a stay of but six months.

A colleague of Frischlin's at Wittenberg was the ill-starred Giordano Bruno. They had in temperament and interests but little in common. Frischlin was not at all interested in the subtleties of formal philosophy. They did share, however, the same poverty. Bruno later told Crusius that Frischlin had told him of receiving a considerable yearly stipend from the Emperor. Bruno had promptly journeyed to Prague to seek the same. Nothing, of course, ever came of it, for Frischlin had not told the truth. The incident reveals something of Bruno's credulity and more of Frischlin's character. By telling Bruno the story Frischlin did rid himself of a brilliant rival for student affection and fees at Wittenberg, though this was probably not his primary motivation. Frischlin wanted recognition of his talents, and failing that, he was not averse to inventing it. But at this point such inventions may well have been beyond his conscious control. One suspects that Frischlin believed his lie. In claiming recognition, recognition was his in his mind. His psychic reality momentarily defeated real reality, fantasy became reality, failure became success.

Settling down in Braunschweig to his teaching duties, Frischlin was 
eventually prevailed upon by his friends to seek a reconciliation with Crusius. He made an attempt, sending a letter to Crusius in which he placed the blame for their fight on the malevolence of other parties who, he said, had incited the enmity between the two men. This of course was patently false, but Strauss is probably correct in stating that this polite fiction was the only feasible way out of their hostilities. Crusius would not accept Frischlin's offer to recant all that he had written against him if Crusius would reciprocate. Crusius undoubtedly saw himself as the injured party and he self-righteously sought to place all the blame on his ungrateful former pupil.12 Thus no reconciliation was brought about, though Frischlin's letter served him well among both his friends and enemies in Tübingen.

Frischlin was not particularly satisfied with his low paying position in Braunschweig and Strauss reports that he found neither the local air, the local water, nor the local beer to his liking. ${ }^{13}$ With the hope of support from the Landgrave of Kassel, which later proved unfounded, he gave notice to Leyser in the summer of 1589. Before departing from Braunschweig, however, he composed an anti-Philippist Schwank, Die Pritschmeister Reime, in which he stated that Melanchthon was a Zwinglian and that the regime of Saxony suppressed the true Lutheran teachings. This he did as a favor to Leyser, who as an orthodox Lutheran had lost his professorship at Wittenberg a short time previously. Frischlin may have harbored a personal bitterness towards Wittenberg as well, since no offer of a permanent position had been made while he was there. The Philippists were understandably upset and made preparations for Frischlin's arrest on his return from Hessia. Warned by his friends, Frischlin did not bother to go back to face incarceration in the Philippist stronghold. The orthodox party in Braunschweig sent Frischlin a document praising his activities in their school.

Frischlin then went to Marburg by way of Helmstedt where he was feted by the vernacular dramatist, Duke Heinrich Julius von Braunschweig. From Marburg, where he left his family, Frischlin travelled about feverishly, going to Speyer to institute legal action against his foes in Braunschweig. He may have even gone to Copenhagen seeking help. In his absence he and his family were told to leave Marburg and were allowed to remain only because Frischlin's wife was in the last stages of pregnancy. Frischlin's predicament was now extremely desperate. He sought aid again in Kassel - with no result. Settling finally near Frankfurt am Main, Frischlin turned to Duke Ludwig, asking that his wife's legacy from her father be freed. He wanted to establish his own press to publish his works and needed the money for this undertaking. Duke Ludwig refused this request on the advice of friend and foe alike, all of whom maintained that Frischlin was incorrigible. Plans were laid for bringing him back to Württemberg to face punishment for having broken his oath. Extremely distressed by its refusal of his plea, Frischlin wrote a bitter 
letter to the court at Stuttgart, exclaiming that he did not deserve such ill treatment from a ruler he had served so well. He preferred to believe that the letter's authorship was not the Duke's but that of his enemies at court. In short, he stated that he was not yet reduced to begging, and that the tone of the letter from Stuttgart was highly offensive to him. He signed the letter, "Nicodemus Frischlinus, Med. e. Philos. Dr., Poëta coronatus, Palatinus Rudolphi Caesaris." 14 The first of these three titles was an affectation; the highest academic degree Frischlin attained was a Master's degree under Crusius. Again, Frischlin publicly claims a title not properly his.

Frischlin's letter sealed his fate. It was decided that he must be arrested and incarcerated until he came to his senses. Stahlecker is correct in pointing out that the men who reached this decision were in large part Frischlin's former supporters. Indeed, Crusius played no role in it. In April of 1590 Frischlin was finally arrested in Mainz, much to his surprise. Held for a time in the Schloss Wirtemberg, Frischlin declared himself ready to accept the judgment of his prince and to make no attempts to escape. Unfortunately, a highly incriminating letter from the captive to the Emperor came into the wrong hands. In this letter Frischlin swore all allegiance to the Habsburgs and hinted at his willingness to convert to Catholicism. ${ }^{15}$ The effect of this letter on the Protestant court at Stuttgart can be imagined. Frischlin was almost immediately transferred to the fortress of Hohenurach where tighter security prevailed.

At Hohenurach he was forbidden contact with the otuside world and was placed in solitary confinement. At first he was forbidden any writing material but as the year progressed the conditions of his confinement improved. It was at this time that Frischlin completed his Hebräis, an epic poem celebrating the children of Israel. This must have given him some satisfaction. He also composed or outlined a number of vernacular projects, including the fragmentary drama, Ruth. His writings in German were not highly appreciated by the censors to whom he had to submit them.

The aim of the Duke seems simply to have been to keep Frischlin in prison long enough to teach him a lesson. Frischlin had to accept the blame for his predicament and his supplications to the court did become gradually more self-recriminatory. This pleased his friends at Stuttgart, though they gave Frischlin little hope for release. By the end of November 1590 , Frischlin had fallen into a deep depression. Though it is probable that Frischlin was shortly to be permitted to rejoin his family under house arrest, not the slightest inkling of this was given to the prisoner. The desperate Frischlin tried to escape, having fashioned a rope from his bedding. The rope broke and Frischlin fell to his death. The papers and notes which Frischlin left behind were ordered destroyed by the Duke. This gave rise to rumors concerning their contents. One of the more bizarre of these was to the effect that Frischlin confessed himself to be 
neither Lutheran, Calvinist, nor Catholic, but Arian! ${ }^{16}$ Frischlin was buried in a common cemetery in a place apart from the other graves. There seems to have been some suspicion of suicide, though he received benefit of clergy at his graveside and nothing was ever officially published in this regard.

What then can we say of the picture we have of Frischlin? What Strauss tries to paint as tragedy, we feel more disposed to represent as something less. Strauss sees Frischlin as a martyr; he refers to him as a saint on more than one occasion. I think it clear that Frischlin was not a very saintly man, nor was he a very willing martyr. Frischlin's fate had nothing to do with his own conscious volition. Stahlecker is rather hostile to Frischlin but perhaps he understands his man better than does Strauss. Strauss makes Frischlin the prototype of the creative spirit in conflict with an unforgiving, basically Philistine system. Stahlecker is more tolerant of the system and highly critical of Frischlin's polemic excesses. What Stahlecker seems to grasp better than Strauss is Frischlin's pronounced ambition. Perhaps because Strauss was possessed by the same burning drive for recognition, he failed to see, or at least failed to stress, this as the central trait in Frischlin's character.

Frischlin was indeed a talented man, the most gifted Latinist of his era. He knew this, and humility was not a part of his make-up. Quick of wit and fond of food and drink, Frischlin made friends and enemies with equal ease. He made no secret of his desire to be known as a new Virgil he made no secret of his high esteem for his own erudition and creativity. Such a man was bound to arouse misgivings among his more pedestrian colleagues.

Because of his youth, it was unlikely that he could have received a senate position as soon as he wished even had his personal behavior as a young professor been above reproach, which it was not. Not content with a quiet academic career, Frischlin also wished to play the courtier. His Ducal and Imperial favor did him ill in Tübingen where he seemed to flaunt it. As an academic, Frischlin's atittude towards the nobility was ambivalent. He had been officially raised to the level of lesser nobility, yet he was not accepted as an equal. He had the duties of a professor, yet he was excluded from the university's governing body. Frischlin was acceptable in neither world in which he sought recognition. We witness the paradox of the man of consummate ambition becoming the extreme outsider. Philologist and poet, blithe spirit and pater familias, a productive scholar and congenial companion - the many roles Frischlin chose to play did not foster an emotional security. He often lamented the fact that the recognition afforded him was meager considering his services, pedagogical, literary, and scholärly. Frischlin is one of the few writers of his age to make social commentary, to act as a contemporary critic of the values of his society. His own role playing must have sharpened his critical insight. And beyond this, there is the repeated frustration of his 
own goals. Profoundly ambitious, but excruciatingly frustrated, Frischlin's many difficulties, particularly in the period following his return from Laibach, seem to have actually unbalanced him. Both his friends and others noticed this. His repeated public assumption of titles and favors unconferred indicates that he actually believed they had been granted. One may question his grasp of reality, and while his obsession with recognition and acceptance, even from the earliest period, borders on the pathological, Frischlin appears intent upon a path towards failure. The psychological pattern forming Frischlin's character seems clear enough. He was his own worst enemy, for no one may test the patience of his friends, nor make such demands for uncritical acceptance as Frischlin did and escape unscathed. Frischlin's was a disordered, inconsistent, and ambivalent character, and while in this he may share much with many more glorious martyrs, his own "martyrdom" he surely imposed upon himself.

Yet, if a culture may be understood by the quality of its social eccentrics, then in Frischlin's fate, and in his subsequent oblivion, is mirrored the fate of his age. For Frischlin's eccentricity lies in his extreme acceptance of the values of his age rather than in any nonconformity. Frischlin's life and works may be seen as almost paradigmatic for his time. In Frischlin we see the tendencies of his age distorted and magnified, brought into bold relief by his extremes. His character was shaped by what his society had to offer. His contemporaries understood him well. They were right. He was incorrigible, and given his temperament, his fate seems almost inevitable.

University of Michigan

SAMUEL M. WHEELIS

Ann Arbor

\section{Notes}

1. Leben und Schriften des Dichters und Philologen Nicodemus Frischlin (Frankfurt a.M., 1856). Herafter referred to as Strauss.

2. "Martin Crusius und Nicodemus Frischlin", Zeitschrift für würtembergische Landesgeschichte. Bd 7. (Stuttgart, 1943), pp. 323-366. Hereafter, Stahlecker.

3. A refreshing view of Frischlin is offered by Joachim G. Boeckh in ,,'Gastrodes' Ein Betrag zu Salomon Schweiggers 'Eine neue Reissbeschreibung' und zu Nicodemus Frischlins 'Rebecca'", Wissenschaftliche Zeitschrift der Martin-Luther Universität Halle-Wittenberg, Jahrgang 10 (1961), Gesellschafts- und Sprachwissenschaftliche Reihe, Heft 4, pp. 851-957. As a Marxist, Boeckh tends to see Frischlin as a proto-social revolutionary, citing elements in his plays to support this contention. Nonetheless, Boeckh's essay points in the direction of a demythologizing of Frischlin for contemporary students of the sixteenth century.

4. George Schulz-Behrend, "Nicodemus Frischlin and the Imperial Court", Germanic Review, xxx, 3, October 1955, p. 172.

5. Strauss, p. 53.

6. Schulz-Behrend, p. 178.

7. See Strauss, pp. 168-223 for a more detailed account of the entire affair. Seen in the proper perspective, it all appears rather bathetic in spite of (or perhaps because of) Strauss's attempts to counter this impression. 
8. See Strauss, pp. 283-342.

9. Reprinted in Strauss, pp. 576-579.

10. A point stressed by Stahlecker, p. 352 .

11. Strauss, p. 404.

12. Strauss, pp. $428-432$, gives a more extensive treatment of this highly critical period.

13. Strauss, p. 439.

14. Stahlecker, p. 361.

15. Strauss, p. 476 .

16. Strauss, p. 552. 